\title{
Hydrofracturing water boreholes in hard rock aquifers in Scotland
}

$\mathrm{J}_{\text {Cobbing }}{ }^{1}$ and B É Ó Dochartaigh ${ }^{2}$

${ }^{1}$ CSIR Natural Resources and the Environment Unit, PO Box 395, Pretoria 0001, South Africa

${ }^{2}$ British Geological Survey, Murchison House, West Mains Road, Edinburgh EH11

1DZ, United Kingdom (Corresponding author. Email: beod@bgs.ac.uk) 


\begin{abstract}
Hydrofracturing of new public water supply boreholes in Precambrian crystalline bedrock in Scotland has increased borehole yields by at least one order of magnitude, and made the difference between borehole abandonment and success. In many upland rural areas of the United Kingdom, low productivity aquifers are an important resource for small public water supplies. Where a borehole in low productivity crystalline rocks proves too low yielding for its designed purpose, hydrofracturing is a cost-effective means of enhancing yield.
\end{abstract}




\section{Contents}

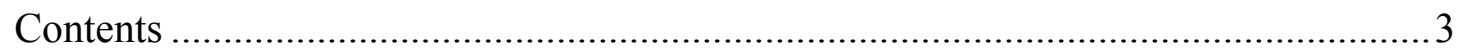

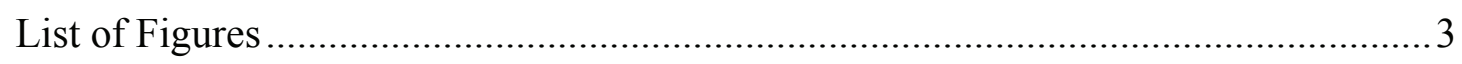

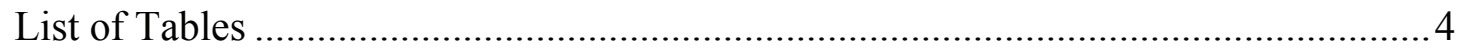

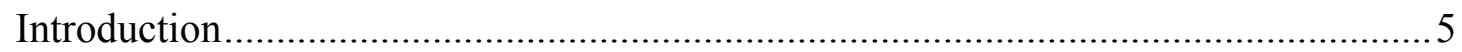

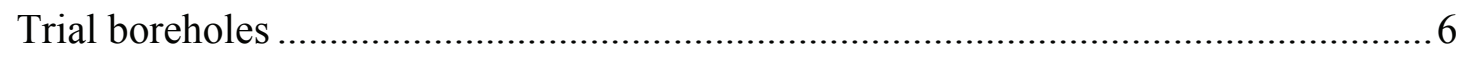

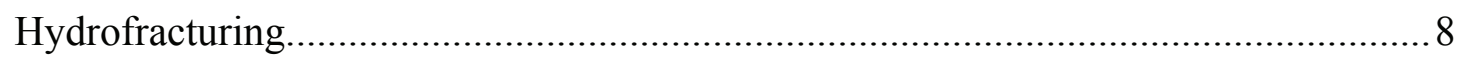

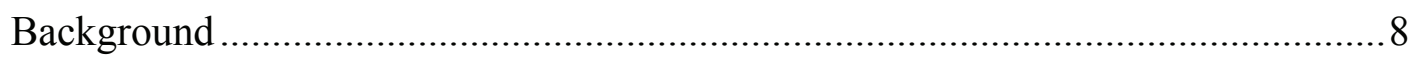

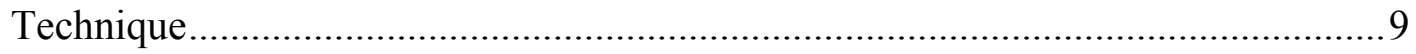

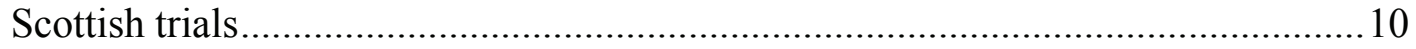

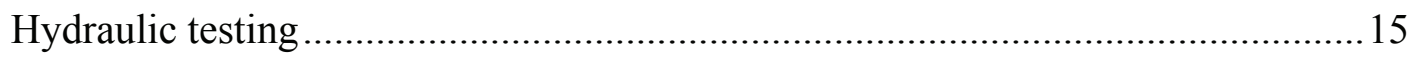

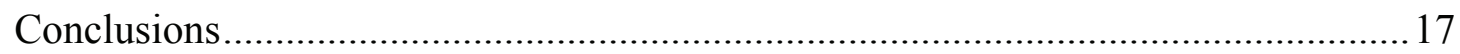

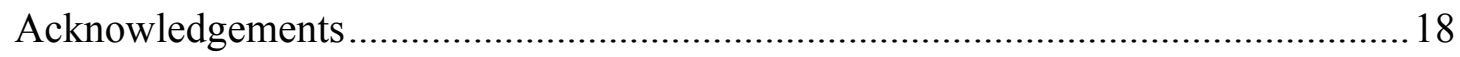

\section{List of Figures}

Figure 1 Locations of Alligin and Laggan Bridge boreholes and the extent of low and very low productivity aquifers in Scotland, as classified by BGS

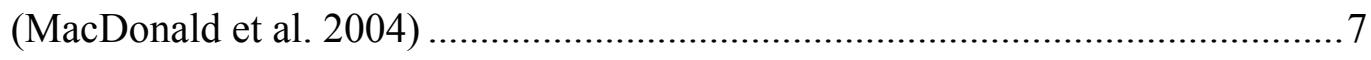

Figure 2 Schematic of the packer used for hydrofracturing ................................ 12

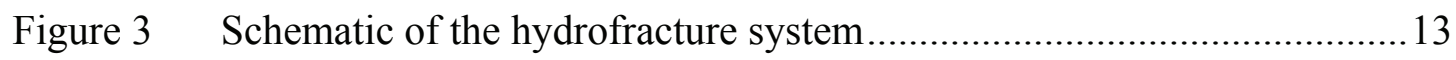

Figure 4 Time-drawdown curves for modelled and observed data for (i) pre- and (ii) post-hydrofracture rising head tests at Alligin, and (iii) pre- and (iv) posthydrofracture rising head tests at Laggan Bridge. 


\section{List of Tables}

Table 1 Summary of boreholes at Alligin and Laggan Bridge …........................ 8

Table 2 Summary of hydrofracturing on boreholes at Alligin and Laggan Bridge..

Table 3 Summary of hydraulic test results on boreholes at Alligin and Laggan

Bridge 15 


\section{Introduction}

Much of the Scottish Highlands is characterised by ancient Precambrian basement rocks, which in their unweathered state have low or non-existent matrix permeability, but which provide secondary storage and permeability in fractures. The success of water supply boreholes depends largely on the number, length, dilation and interconnectivity of fractures encountered on drilling. At best, boreholes are capable of yields of up to approximately $20 \mathrm{~m}^{3} /$ day; in the worst cases where no suitable fractures are encountered, boreholes are dry. Boreholes in Precambrian rocks are therefore typically suitable for domestic or small farm supplies, where yields of 1 to $10 \mathrm{~m}^{3} /$ day are sufficient, but not for larger supplies. MacDonald et al. (2005) estimate that there are more than 20000 springs, wells and boreholes used for private water supply in Scotland, most of which are in remote rural areas, often in the Highlands, tapping Precambrian basement aquifers. However, until recently, most public water supply boreholes in the Highlands tapped high-yielding sand and gravel aquifers in major river valleys.

In 2004, Scottish Water, looking to improve public water supplies to a number of scattered, small Highlands communities, investigated the further development of groundwater supplies from Precambrian metamorphic and highly indurated sedimentary rock aquifers in the Highlands. Supplies of up to $45 \mathrm{~m}^{3} /$ day were required for each community, each of which is located in areas where high permeability superficial aquifers are absent or are unsuitable for public water supply, for example because of poor water quality. Local groundwater development was preferable to the further development of surface water resources, for reasons both of cost and the environmental sensitivity of these remote areas. Hydrofracturing was 
identified as a technique with the potential to improve the normal expected borehole yields to the required level. This note describes data from two boreholes, where detailed testing before and after hydrofracturing allowed yield increases of more than one order of magnitude, attributable to hydrofracturing, to be quantified.

\section{Trial boreholes}

The two trial boreholes are at separate sites in the Scottish Highlands: Alligin in Wester Ross, and Laggan Bridge in Invernessshire (Figure 1). The approximate public water demand at Alligin is $45 \mathrm{~m}^{3} /$ day, and at Laggan Bridge is $25 \mathrm{~m}^{3} /$ day. Borehole siting was governed by logistical, land ownership, and hydrogeological factors. The Alligin borehole was drilled by Drilcorp Ltd, and the Laggan Bridge borehole by Raeburn Drilling and Geotechnical Ltd. Both boreholes were hydrofractured by Drilcorp Ltd. At each site, BGS hydrogeologists supervised the borehole drilling, testing and hydrofracturing on behalf of Scottish Water Solutions. Borehole details are summarised in Table 1. 


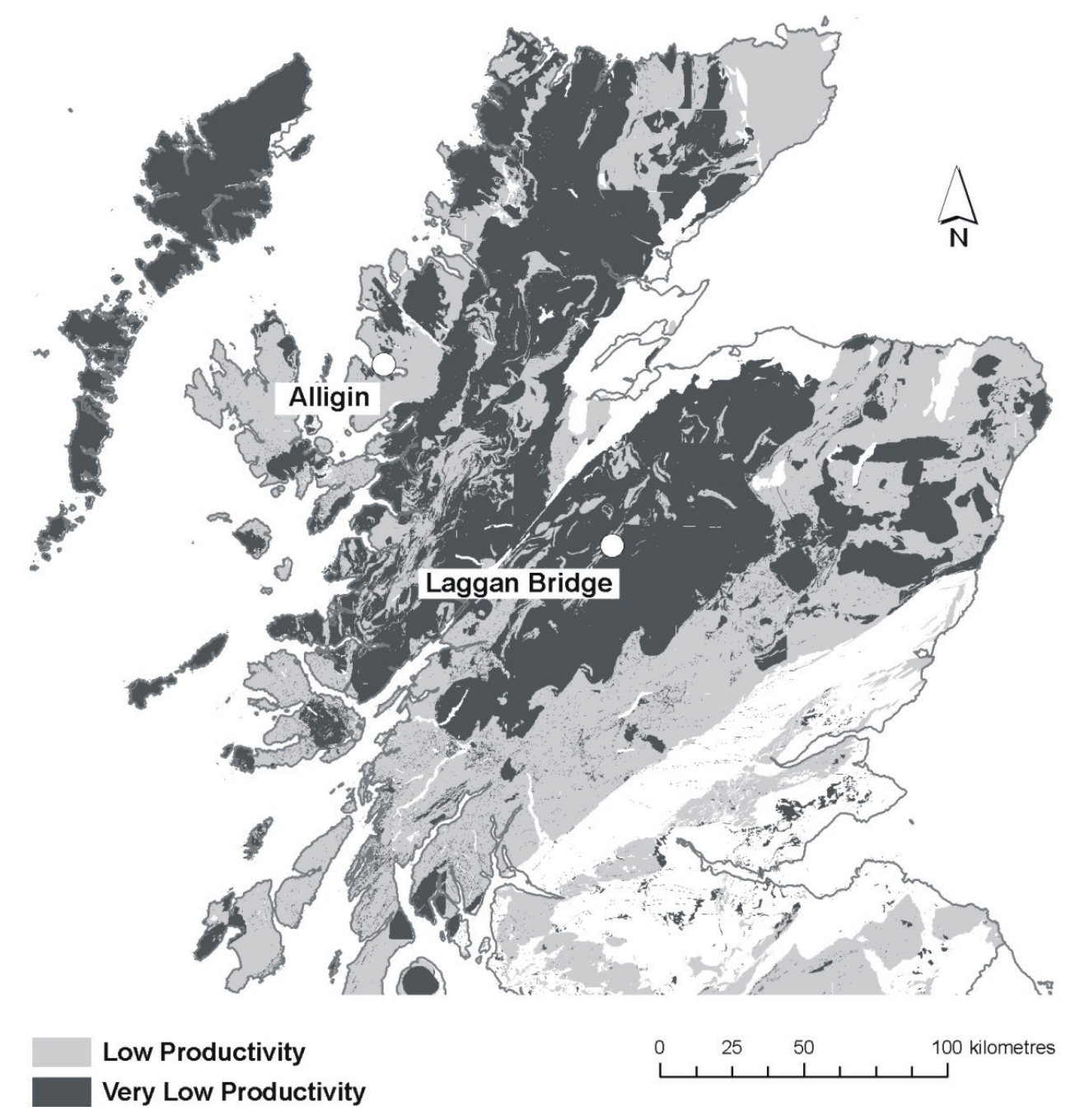

Figure 1 Locations of Alligin and Laggan Bridge boreholes and the extent of low and very low productivity aquifers in Scotland, as classified by BGS (MacDonald et al. 2004) 


\begin{tabular}{|c|c|c|c|c|c|c|}
\hline Borehole & Easting & Northing & $\begin{array}{l}\text { Depth } \\
\text { (m) }\end{array}$ & $\begin{array}{l}\text { Depth of } \\
\text { surface } \\
\text { casing } \\
\text { (m) }\end{array}$ & $\begin{array}{l}\text { Diameter } \\
(\mathrm{mm})\end{array}$ & Bedrock geology \\
\hline Alligin & 183158 & 858246 & 83.5 & 8 & 200 & $\begin{array}{l}\text { Applecross } \\
\text { Formation } \\
\text { (sandstone) to } \\
79.8 \mathrm{~m} \text {; Scourian } \\
\text { Gneisses from } \\
79.8-83.5 \mathrm{~m}\end{array}$ \\
\hline $\begin{array}{l}\text { Laggan } \\
\text { Bridge }\end{array}$ & 261092 & 794349 & 100 & 34 & 200 & $\begin{array}{l}\text { Grampian Group } \\
\text { (gneissose } \\
\text { psammites and } \\
\text { semipelites) }\end{array}$ \\
\hline
\end{tabular}

Table 1 Summary of boreholes at Alligin and Laggan Bridge

\section{Hydrofracturing}

\section{Background}

Hydrofracturing of new and existing water boreholes to increase yields is routinely carried out in the United States, and has also been used successfully in other parts of the world, including Scandinavia, South Africa, India, and Australia. 
The technique acts to enhance borehole yields, by injecting high-pressure water into a borehole in order to create and enlarge fractures in the surrounding rock. Hydrofracturing also acts as a borehole development technique, clearing loose sediment from existing fractures. It does not increase the storativity of the aquifer, but effectively widens the influence of the borehole so that it draws from a greater area of storage. The pressure required to create new fractures, and the degree of yield improvement, varies considerably according to rock tensile strength and stresses and permeability, and on the initial yield of the borehole (Less 1994, Less and Anderson 1994, Schuring 2002, Ramsted 2004). Various studies report that minimum yield increases of $20 \%$ and average increases of at least $80 \%$ are achieved in between 40 and $70 \%$ of hydrofractured boreholes, with the largest improvements seen in rock formations with lower initial permeability, particularly crystalline rocks (Joshi 1996, Less 1994, Less and Anderson 1994, Herbert et al. 1993, Shuring 2002). Where boreholes are dry prior to hydrofracturing, they typically show little or no improvement (Joshi 1996). Studies have also concluded that improving borehole yields by hydrofracturing is more cost-effective than drilling new boreholes (Joshi 1996, Less and Andersen 1994, Talbot et al. 1993).

\section{Technique}

Hydrofracturing is carried out in the open, uncased section of a borehole, below the casing and the water table. The interval to be hydrofractured is hydraulically isolated using packers: a single packer is used to isolate the hole below the packer, or two packers used to isolate a discrete interval, typically a known fracture horizon. Water is pumped through the centre of the top packer into the zone to be hydrofractured. The pressure within the packered interval until a level is reached at which fractures in the 
surrounding rock are enlarged, or new fractures are created. This pressure varies, from approximately 35 bar in softer rocks, to over 140 bar in harder rocks (Ramsted 2004). Fracture opening causes a drop in the injected water pressure, and increased flow of water into the rock. Pumping of water into the packered interval then continues to develop the fractures, at rates of up to approximately 300 litres/minute. After hydrofracturing, the injected water is normally pumped or airlifted from the borehole, together with any debris arising from the process. Caliper logging is often carried out prior to hydrofracturing, and other downhole geophysical logging or television surveys may also be run, both to determine fractured zones which might be enhanced by the technique, and to locate suitable positions on the borehole walls where the packers might be placed for optimal sealing. Hydrofracturing can also affect nearby boreholes, as evidenced by rising water levels (e.g. Ó Dochartaigh et al. 2005). Solids such as glass beads or sand can be added to the injected fluid as propping agents or 'proppants' to keep open newly developed fractures, but studies have shown that they do not always increase the effectiveness of the technique (e.g. Ramsted 2004).

\section{Scottish trials}

A single packer system designed by Drilcorp Ltd was used on both trial boreholes. The packer (Figure 2) was placed initially near the top of the borehole, but a few metres below the base of the casing in order to prevent damage to the casing seal. It was expanded by means of a single acting hydraulic ram controlled at the surface by a hand-operated pump, typically to a pressure of around 415 bar. The hydraulic oil used to expand the packer via the ram was biodegradable in case of leaks, and was pumped to the packer via a high-pressure hydraulic hose. A steel release cable was attached to 
the top of the packer, so that in the event of the packer failing to contract when the hydraulic oil pressure was released, it could be used to force the packer to contract. Potable water was then pumped through the steel pipe and packer and into the interval to be pressurised. The high-pressure water pump consisted of a diesel motor connected via a gearbox to a triplex pump capable of $240 \mathrm{~m}^{3} /$ day at $140 \mathrm{bar}$. The volume and pressure of water from the pump to the packered interval was controlled using a system incorporating two pressure gauges, two non-return valves and three gate valves mounted on a steel trestle, which allowed the pressure of the water to the packered interval to be closely controlled (Figure 3). Once a fracture or set of fractures had been developed, and the pressure had dropped, the packer was contracted and lowered below those fractures to pressurise another unfractured section of the borehole. New fractures can only be developed below existing fractures using the single packer system. 


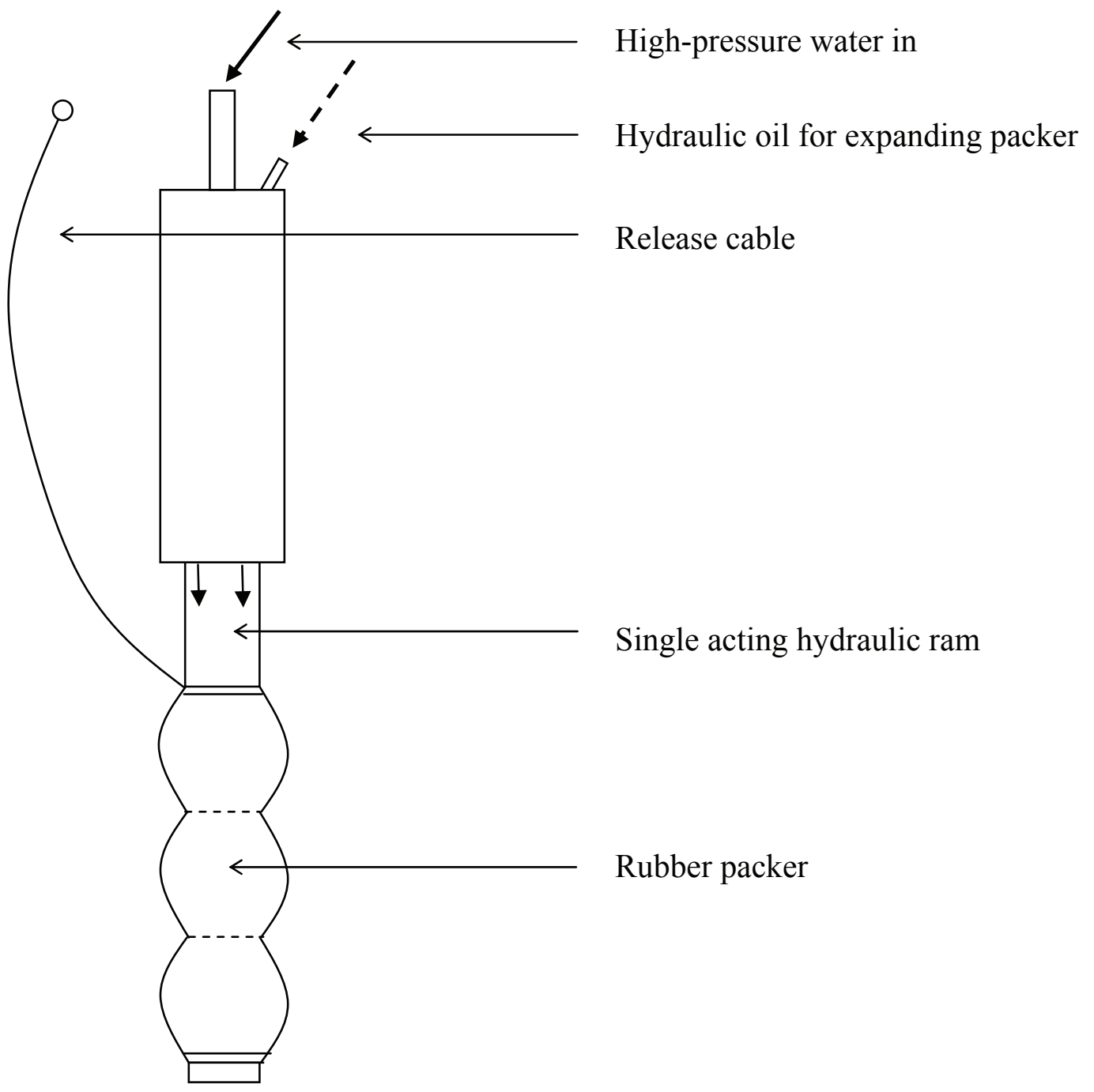

Figure 2 Schematic of the packer used for hydrofracturing 


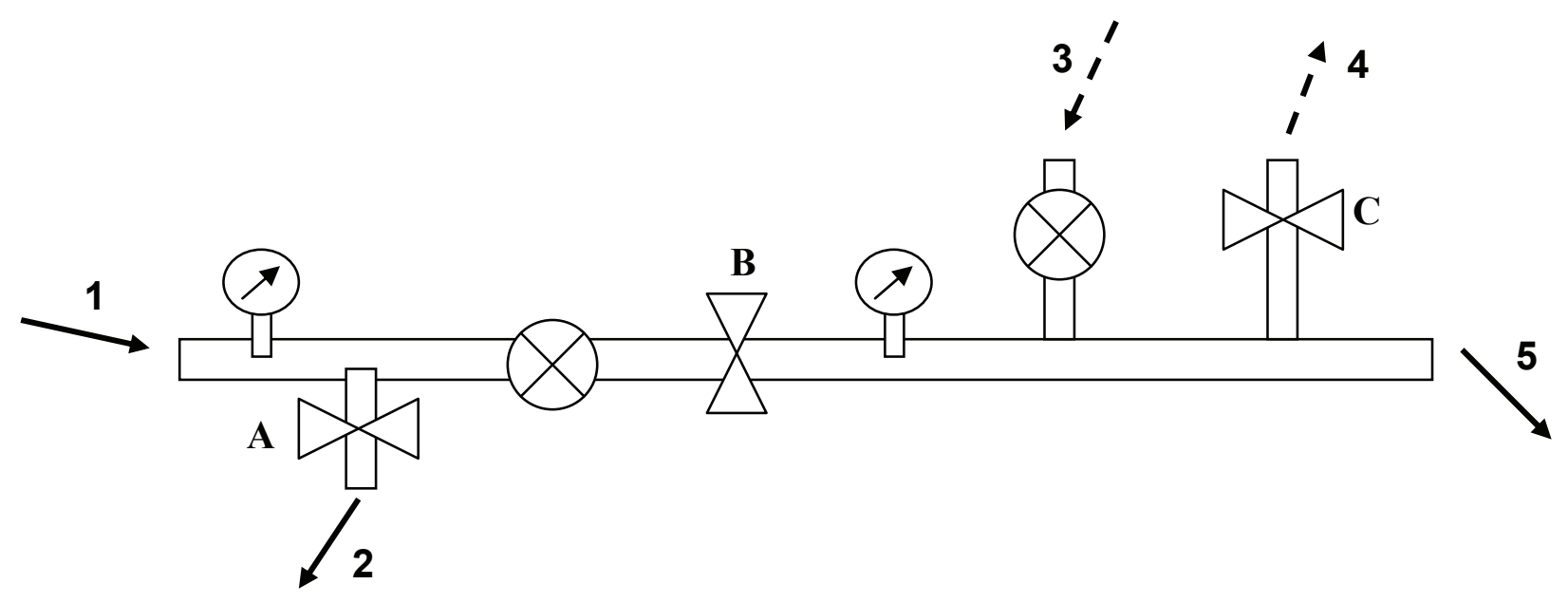

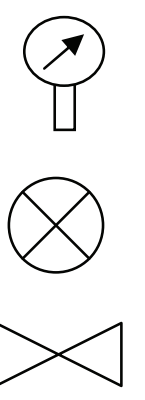

Pressure gauge
(200 bar)

Non-return valve

High pressure gate valve
1. High pressure water from pump.

2. Discharge of water back to supply for controlling pressure.

3. Injection of high pressure water from rig pump if necessary.

4. Pressure release valve.

5. High pressure water to borehole.

Figure 3 Schematic of the hydrofracture system

The system incorporates two pressure gauges, two non-return valves and three gate valves.

The first pressure gauge monitors the pump output pressure (1), which can be reduced by gate valves (A and B), allowing some water to return to the water store (2) if necessary. The water then flows through a non-return valve to the borehole (5). A second pressure gauge, mounted after the non-return valve, monitors the water pressure in the borehole. Provision for the injection of further high-pressure water from the drilling rig pump is made via a second nonreturn valve (3). The system was equipped with a pressure release port (4) controlled by a gate valve $(\mathrm{C})$, allowing the water pressure to be released at the end of the procedure. 
At each trial borehole, Alligin and Laggan Bridge, four hydrofracture runs were carried out over two days, with the packer successively moved to deeper horizons. A summary of the runs is given in Table 2 . In each case, the maximum pressure was reached only a few minutes into the run, with the pressure tending to increase as a series of sharp 'kicks' rather than as a steady increase. The maximum pressure varied from 35 to more than 120 bar, but was most often between 50 and 70 bar. After reaching the maximum in each run, the pressure dropped, generally to between 17 and 35 bar, and maintained at this level as more water was pumped in. This pattern is interpreted as the creation, widening or clearing out or more fractures at the highest pressure, which then form an outlet for the water being pumped in, thus limiting the pressure which can be maintained beneath the packer. The nature and extent of bedrock permeability is the major control on the pressures that can be achieved during hydrofracturing, although a higher pressure pump with a larger flow capacity may be able to raise the maximum and holding pressure further.

\begin{tabular}{llllll}
\hline Borehole & $\begin{array}{l}\text { Number of } \\
\text { hydrofracture }\end{array}$ & Depth & Maximum & Average & Total volume \\
& runse of & pressure & steady & water \\
& & packer & achieved & pressure & injected $\left(\mathbf{m}^{\mathbf{3}}\right)$ \\
& & $(\mathbf{m})$ & (bar) & (bar) & \\
\hline Alligin & 4 & $13-58$ & 120 & 35 & 5.7 \\
\hline Laggan Bridge & 4 & $40-85$ & 70 & 17 & 7 \\
\hline
\end{tabular}

Table 2 Summary of hydrofracturing on boreholes at Alligin and Laggan Bridge 


\section{Hydraulic testing}

Rising head tests were carried out on both boreholes before and after hydrofracturing. For both boreholes, post-hydrofracturing tests were carried out at significantly higher flow rates (Table 3). The test results were analysed to estimate transmissivity for the surrounding aquifers, using the software package BGSPT (Barker and Macdonald 2000, Barker 1985) (Figure 4). The transmissivity of both boreholes increased significantly, by more than one order of magnitude, following hydrofracturing (Table 3), from 0.03 to $0.6 \mathrm{~m}^{2}$ day $^{-1}$ at Alligin and from 0.16 to $2.2 \mathrm{~m}^{2}$ day $^{-1}$ at Laggan Bridge. The linear response of water levels in both boreholes before hydrofracturing (Figure 4) points to fracture dewatering and the cascading of water down the boreholes, even at the very low test yields. By comparison, the noticeably different non-linear water level response following hydrofracturing indicates radial flow to the boreholes and no fracture dewatering, even at the significantly higher test yields.

\begin{tabular}{lcccc}
\hline & \multicolumn{2}{c}{ Pre-hydrofracturing } & \multicolumn{2}{c}{ Post-hydrofracturing } \\
\hline Borehole & Yield (l/min) & Transmissivity & Yield (l/min) & Transmissivity \\
& & $\left(\mathbf{m}^{2} / \mathbf{d a y}\right)$ & & $\left(\mathbf{m}^{2} / \mathbf{d a y}\right)$ \\
\hline Alligin & $>5$ & 0.03 & $35-40$ & 0.6 \\
\hline Laggan Bridge & negligible & 0.16 & 18 & 2.19 \\
\hline
\end{tabular}




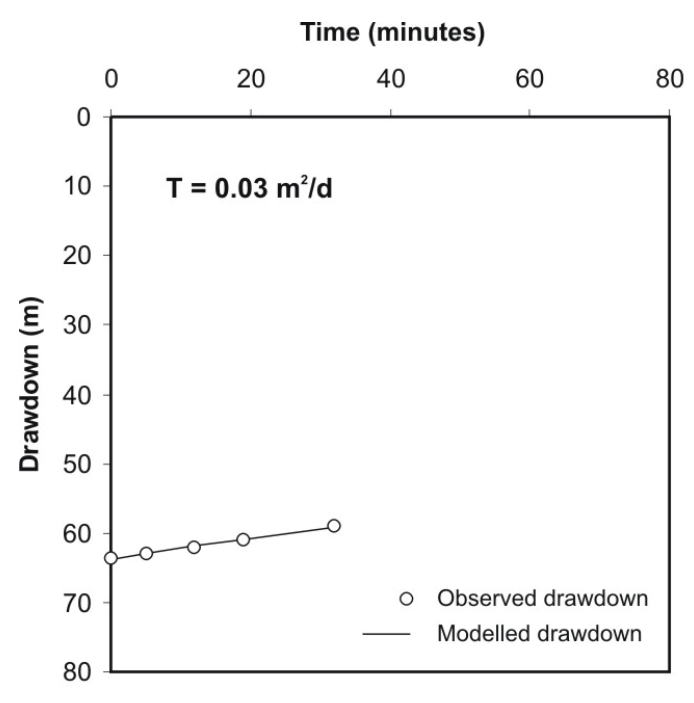

(i)

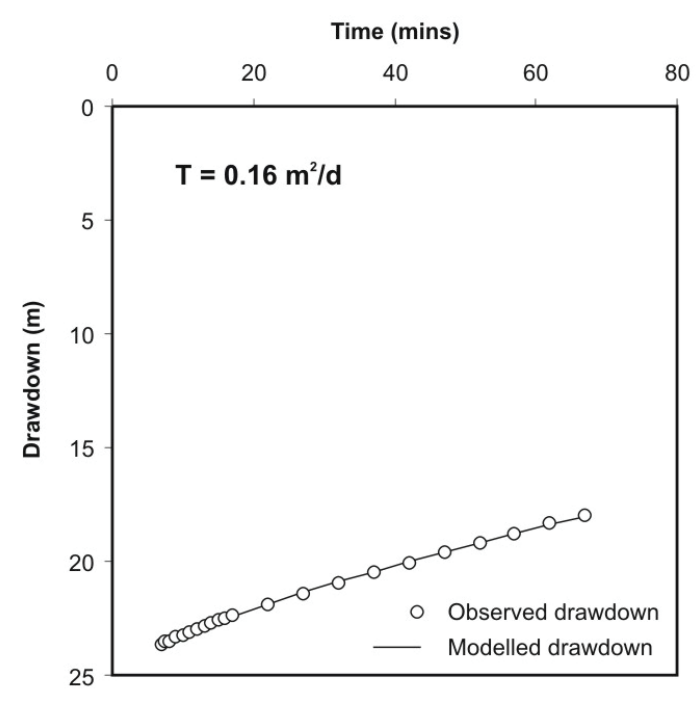

(iii)

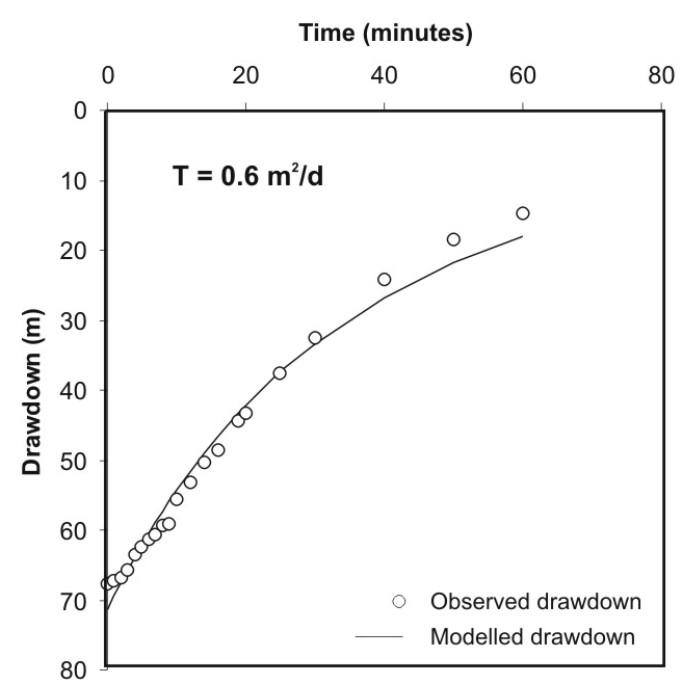

(ii)

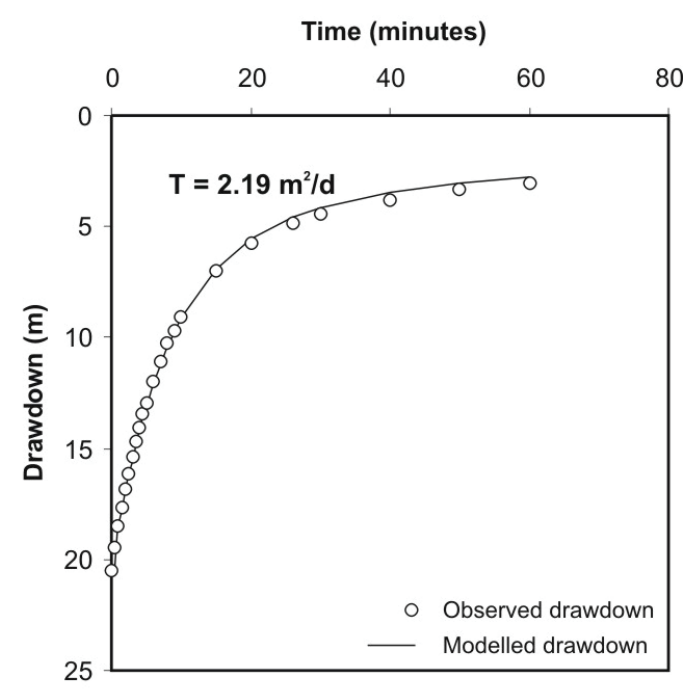

(iv)

Figure 4 Time-drawdown curves for modelled and observed data for (i) pre- and (ii) post-hydrofracture rising head tests at Alligin, and (iii) pre- and (iv) post-hydrofracture rising head tests at Laggan Bridge.

A close agreement between modelled and observed drawdown allows high confidence in estimated transmissivity. 


\section{Conclusions}

Hydrofracturing has increased the yields of two boreholes in Precambrian aquifers in Scotland by at least one order of magnitude, in line with reported results from hydrofracturing in similar aquifers elsewhere in the world. Based on these data, it is not obvious if the main yield increase is due to the increased pressure during hydrofracturing creating new fractures or expanding existing ones, or to a process of borehole development as loose debris or clay is cleared from existing fractures. It is likely that a combination of these factors is in operation. Pumped flow-logging of boreholes before and after hydrofracturing would be a useful tool in determining where new inflow zones might typically be located. Follow-up testing of boreholes would show if the yield increases produced by hydrofracturing are maintained over the long term.

Yield increases following hydrofracturing of boreholes in Precambrian aquifers in Scotland are sufficient to allow the development of groundwater for public water supply, albeit on a small-scale. Hydrofracturing is cheaper than re-drilling to replace low yielding boreholes, particularly when the new boreholes are in any case likely to be equally low yielding. This has important implications for the continued development of groundwater in remote rural areas in Scotland, and other parts of the United Kingdom, where existing surface water supplies often require extensive, expensive and environmentally detrimental water transport and treatment.

Hydrofracturing is not a replacement for informed borehole siting to maximise the chances of obtaining the required yield, but provides a useful additional tool for the hydrogeologist working in hard rock, low productivity terrains. Although such areas 
have often been considered in Africa and other parts of the developing world as part of small scale rural water supplies, the evidence presented here and in other recent studies in areas such as Scandinavia (Ramstad 2004) indicates that the technique may have more wider application in the United Kingdom. Examples of other areas suitable for hydrofracturing may include Palaeozoic indurated sedimentary rocks in the Scottish Borders, the Lake District and Wales, and granites and lavas in Scotland, Northern Ireland and Cornwall.

\section{Acknowledgements}

This work was carried out as part of projects funded by Scottish Water. This paper is published with the permission of the Executive Director of the British Geological Survey (NERC). The authors wish to thank Alan MacDonald of BGS, Dave Gowans of Drilcorp Ltd and Derek Ball of BGS. 


\section{References}

Ball D F and Harrison I B. 1983. Exploratory Drilling for groundwater on the Island of Arran. British Geological Survey Hydrogeology in Scotland Report No. 83/2.

Banks D and Robins N. 2002. An Introduction to Groundwater in Crystalline Bedrock. Norges Geologiske Undersokelse (Geological Survey of Norway). ISBN 82 73861001.

Barker J A. 1985. Generalised well-function evaluation for homogenous and fissured aquifers. Journal of Hydrology 76, pp 143-154

Barker J A and Macdonald D M J. 2000. A manual for BGSPT: programs to simulate and analyse pumping tests in large-diameter wells. British Geological Survey Technical Report WC/00/17, Overseas Geology Series.

Herbert, R., Talbot, J.C. and Buckley, D.K. 1993. A study of hydraulic fracturing used on low yielding boreholes in the crystalline basement rocks of Masvingo Province, Zimbabwe. Memoirs of the XXIVth Congress International Association of Hydrogeologists, Oslo, Norway, 28th June - 2nd July 1993, pp 698-716.

Hydraulic Fracturing Workshop July 2001: Abstracts from a workshop held in conjunction with the $38^{\text {th }}$ U.S. Rock Mechanics Symposium. Washington DC July 7 2001. Sponsored by Schlumberger and CSIRO Petroleum. 
Less C and Andersen N. 1994. Hydrofracture: State of the art in South Africa. Applied Hydrogeology 2/94.

Less C. 1994. Borehole rehabilitation and stimulation - a basic overview of selected techniques and their application. Africa Geosciences Review, Vol. 1 No. 1 pp 21-26.

Joshi V. 1996. Borewell rejuvenation for sustainability. Proceedings, 22 WEDC conference. New Delhi India.

MacDonald A M, Ball D F and Ó Dochartaigh B É. 2004. A GIS of aquifer productivity in Scotland: explanatory notes. British Geological Survey Commissioned Report CR/04/047N.

MacDonald A M, Robins N S, Ball D F and Ó Dochartaigh B É. 2005. An overview of groundwater in Scotland. Scottish Journal of Geology 41 (1), 3-11.

Ó Dochartaigh B É, Ball D F and Griffiths K. 2005. Laggan Bridge: Final report on borehole drilling and testing. British Geological Survey Commissioned Report $\mathrm{CR} / 05 / 170 \mathrm{C}$.

Ramstad R K. 2004. Ground source energy in crystalline bedrock - increased energy extraction by using hydraulic fracturing in boreholes. PhD thesis. NTNU/NGU.

Schuring J R. 2002. Fracturing technologies to enhance remediation. GWRTAC Technology Evaluation Report TE-02-02. 
Talbot J C, Buckley D K and Herbert R, 1993, Hydraulic Fracturing: Further Investigations on its Use on Low Yielding Boreholes in the Basement Rocks of Zimbabwe. British Geological Survey Technical Report WD/93/16. 